\title{
Drought and the fall of Assyria: quite another story
}

\author{
Arkadiusz Soltysiak ${ }^{1}$
}

Received: 6 February 2015 / Accepted: 2 March 2016 / Published online: 11 May 2016

(C) The Author(s) 2016. This article is published with open access at Springerlink.com

\begin{abstract}
A recent Climatic Change paper suggests a relationship between climatic change in the 7th century BCE and the fall of the Assyrian Empire. However, available archaeological and textual evidence does not support the hypothesis that Assyria was overpopulated during this time and for that reason susceptible to outbreaks of drought. Besides long-term climatic variation, inter-annual variability in crops has always been very high in the dry farming areas of Upper Mesopotamia. To cope with this uncertainty, the local population developed several strategies (e.g. storage of agricultural surpluses in granaries and artificial irrigation in river valleys). Finally, slave prices, known to have declined during times of famine, were relatively stable during the entire century suggesting absence of prolonged periods of food shortage.
\end{abstract}

In a recent volume of Climatic Change, Schneider and Adal1 (2014) published a paper suggesting some sort of relationship between climatic change in the 7th century BCE and the fall of the Assyrian Empire. The authors hypothesize that prolonged drought decreased the volume of available crops and that the carrying capacity was exceeded in the core area of Assyria, which was overpopulated at this time. The authors use paleoclimatic proxies from distant parts of the Near East, most of which have relatively low temporal resolution, and one letter dated 15 May 657 $\mathrm{BCE}$ reporting on drought and the lack of harvests, as evidence for the deterioration of climatic conditions. Inferred overpopulation was deduced based on the size of Nineveh, which covered c. 750 ha during this time.

The article by Schneider and Adalı (2014) is written in a very cautious manner, but the authors nonetheless seem convinced that both their model and their data are sufficient for identifying the proposed climatic change as the possible cause of the rapid collapse of the Assyrian state in the last quarter of the 7th century BCE. However, the amount of textual and

This comment refers to the article available at: 10.1007/s10584-014-1269-y. An author's reply to this comment is available at: 10.1007/s10584-016-1677-2

Arkadiusz Sołtysiak

a.soltysiak@uw.edu.pl

1 Department of Bioarchaeology, Institute of Archaeology, University of Warsaw, ul. Krakowskie Przedmieście 26/28, 00-927 Warszawa, Poland 
archaeological evidence currently available to address this question presents a different scenario than that proposed by Schneider and Adalı (2014) from the single letter they discuss.

Firstly, the results of numerous archaeological surveys contest the supposition of overpopulation during the Neo-Assyrian period. It is evident that growth of the total settlement size took place after its collapse in the Late Bronze Age and the beginning of the Iron Age, but this growth did not reach the size noted for the Early and Middle Bronze Age, in spite of efforts by Assyrian kings, who were interested in the re-population of Upper Mesopotamia (Wilkinson et al. 2005). For example, in north-eastern Khabour drainage the total settlement size in the Early and Middle Bronze Age was over 600 ha and in the Neo-Assyrian period, all sites in that area covered more than 100 ha in total (McClellan 1992). Additionally, the exceptional size of Nineveh did not mean that its inhabitants were more exposed to the risk of famine than people from rural areas. This mega-city was located close to the Tigris River and therefore the drifting of grain from upstream provinces (e.g., Cizre Plain), was relatively easy, and doubled grain prices in the capital city compensated for the costs of relatively long distance transportation (cf. Fales 1996).

Large parts of Upper Mesopotamia were suitable for dry farming, but high inter-annual differences in precipitation made crops unpredictable. However, since at least the Early Bronze Age ancient farmers were aware of this risk and stored their surpluses in granaries, which enabled their survival during 'non-existent years', as they referred to years without crops (Eph al 2009). Spacious buildings interpreted as granaries with capacity that exceeded yearly consumption of a local population have been identified at several sites of Upper Mesopotamia (Fortin 1997; Pfälzner 2002; Paulette 2013).

It is not possible to estimate the total space of royal granaries during the Neo-Assyrian period, but one letter dated to the reign of Sargon II summarizes the daily and monthly ratios that may have been issued by royal, temple and municipal granaries in the town of Kar-Assur, and the available monthly victualing accounts for ca. 2,115,000 1 for human consumption and ca. 1,734,000 1 of fodder, which would provide suitable amounts of food for a minimum of 70,000 people and up to 120,000 people if the fodder was also consumed by humans (Fales 1990). Eighty per cent of this volume was under direct control of the king. This single text strongly suggests that the Assyrian state was well-prepared for potential drought outbreaks.

Food storage was the primary insurance policy of the state, but some other actions also decreased the risk of inter-annual weather variability (cf. Wilkinson et al. 2005). Assyrian armies confiscated the granaries of cities they defeated (Hasel 2008), and irrigation networks in the core provinces (Altaweel 2008) and along the middle Euphrates (Masetti-Rouault 2010) made crops more predictable in these areas. Furthermore, mass deportations enabled better use of available resources and may have served as a relatively fast reaction to any local environmental changes.

Taking all of the above into account, there is nothing to support the hypothesis that the NeoAssyrian state was particularly susceptible to climatic change. On the contrary, periodical drought outbreaks may even have strengthened the central authority, which controlled most grain surpluses and therefore benefited from high grain prices during 'non-existent years', an economic mechanism that is well presented in the Biblical story of Joseph's activity in Egypt (Genesis 41:56).

There is only limited evidence of grain prices during the Neo-Assyrian period; they obviously fluctuated between seasons, depended on transportation costs, and rose during the 'non-existent years' (Vargyas 2001), as well as during military campaigns, and particularly in cities under siege (Eph al 2009). Some contracts from Babylon, dated to a two-year siege period by Assyrians (650-648 BCE), note prices of barley that were up to 60 times higher than usual (Frame 1999). During the same time prices for slaves substantially decreased, as the 
costs for slave sustenance was high, and many people sold their children just to have some food to survive (Frame 1999; Eph al 2009).

This relation between famine and slave prices, attested to in hardship documents from Babylon and other cities under siege, allow for some limited insight into the risk of famine during the 7th century BCE. Several dozen slave selling contracts were found in the archives of Nineveh, Kalhu, and Assur, three major cities of the Neo-Assyrian Empire (Fales 1996). The sample size is small, but some rough comparisons of prices during three periods from 700 to 676,675 to 649 , and 648 to 612 BCE show no significant differences in the average price of slaves for either male (22 contracts) or female (31 contracts) (see Fig. 1). For both sexes, a small decrease in average price may be observed for the period from 675 to 649 . This may, at least in part, be due to the effect of a drought reported for $657 \mathrm{BCE}$, as two female slave selling contracts (marked with a dot) were dated to this year and both prices were for $1 / 3$ mina of silver, a less than average price. There are many caveats that should be kept in mind when this type of data is analysed (cf. Fales 1996), but at least we can see here a similar pattern for two independent datasets concerning males and females, with no evidence of a gradual decrease in slave prices towards the end of the Neo-Assyrian period.

When all the above data are taken into account, it becomes evident that: (1) there are substantial doubts about whether the 'carrying capacity' model adopted by Schneider and Adalı is valid for the Neo-Assyrian Empire, and (2) available price data does not support the hypothesis of a long-lasting famine during the 7th century BCE.

The paper by Schneider and Adalı discusses only the 'carrying capacity' model, but there is another model that links climatic change with social upheaval in the farming areas of

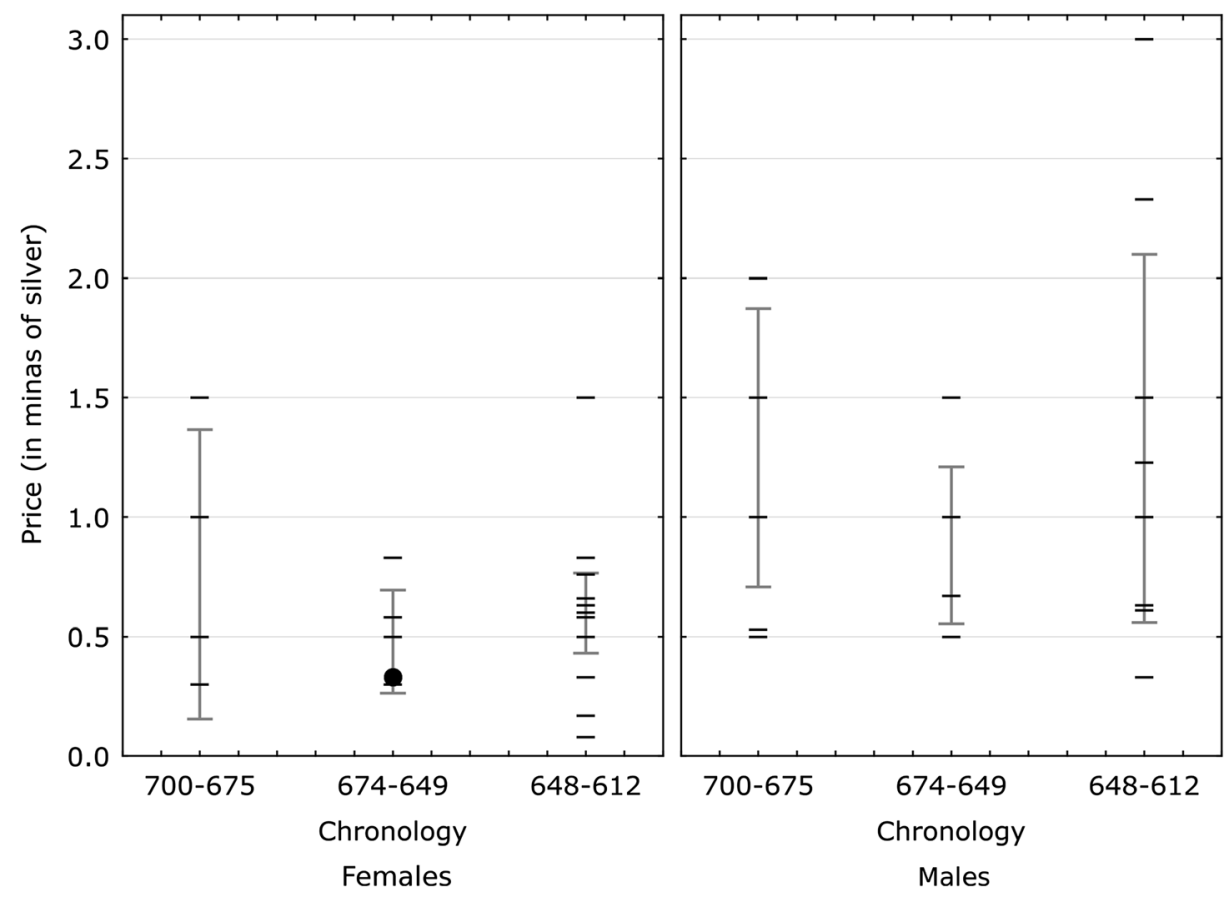

Fig. 1 Individual female and male slave prices during 7th century BCE Assyria (black lines). The $95 \%$ confidence range for mean is marked by grey whiskers. Two prices from 657 BCE are marked with a dot. Raw data from Fales (1996) 
Mesopotamia, as first proposed by Brinkman (1968) and later developed by others (Neumann and Parpola 1987; Kirleis and Herles 2007). In this model, adopted primarily for interpretations of the fall of the Assyrian and Babylonian states at the transition from the Late Bronze to the Iron Age (12th century BCE and later), territorial states based on farming were ruined by mobile herders who isolated the cities from their hinterlands. While farmers were able to survive even a series of drought years using their granaries, for herders even one year of significant drought could cause the death of their entire flocks, as pastures in the dry steppe turn into desert. For them, migration to more humid areas and grazing on arable fields was the only way to survive; however, at the same time, this led to a decrease in cereal production. Once triggered, this incursion of herders caused chaos and the rapid decay of the central administration (Neumann and Parpola 1987; Kirleis and Herles 2007).

This model is widely accepted in the interpretation of events that occurred during the 12th century BCE, when climatic change (cf. Kaniewski et al. 2010, 2013) was contemporary with the rapid expansion of the Arameans from the dry steppes beyond the Euphrates across the entirety of Mesopotamia, initiating a 'dark age' in Assyrian and Babylonian history lasting several centuries (Brinkman 1968; Kirleis and Herles 2007).

The traditional 'herder invasion' model deserves some attention in the context of the fall of Assyria, for during the 7th century BCE nomadic pastoralists were also operating in Upper Mesopotamia. In the same letter from Akkulanu to Assurbanipal, in which we found the passage about the lack of harvesting discussed by Schneider and Adal1 (2014), there is also information about Cimmerians who occupied 'the land of Amurru' (i.e., the eastern part of the Assyrian Empire) during this time (Parpola 1993). The Cimmerians came to the Near East from the steppe north of the Caucasus and were first noted by the Assyrians around 716 BCE. During the reign of Esarhaddon and the early years of Assurbanipal, the Cimmerians were considered a major threat to the Assyrian Empire (cf. Adal 2009) and were finally defeated around 641 BCE (Bridgman 1998).

The Aramean and Cimmerian cases differ from one another, as the latter group came from outside the Near East. However, if migrations of nomadic pastoralists are related to climatic change (cf. Fang and Liu 1992), their presence in Mesopotamia may be the result of an episode of more arid conditions suggested by paleoclimatic proxies, as discussed by Schneider and Adalı (2014). At any rate, the Cimmerians did not enter into permanent control of the land as had the Arameans five centuries earlier, and therefore they cannot be interpreted as the direct causative agent of the fall of the Assyrian Empire.

It is possible to speculate about various scenarios in which climatic change can indirectly be associated with the fall of Assyria. However, the available data are not precise enough to indicate anything more than the fact that there is no single piece of evidence suggesting climatic change contributing to the fall of Assyria, neither within the 'carrying capacity' model of Schneider and Adalı (2014), nor within the traditional 'herder invasion' model. Schneider and Adalı (2014) refer in their paper to the recent outbreak of drought in Syria and suggested that this was the cause of the civil war that has been devastating the country since 2011 . However, even in this contemporary case, the direct relation between weather conditions and political history is disputed and it seems that the large-scale mismanagement of resources lasting for several decades rather than two years of drought triggered the social upheaval and rebellion against the regime (De Châtel 2014), casting even more doubt on the idea that Assyria fell due to climatic change.

This discussion about drought in Assyria may also lead to a more general conclusion. Since the introduction of processual archaeology in 1960s (and even earlier), the relationship 
between climatic changes and collapse of human societies has become an important topic of research on past human societies (Van de Noort 2011). This is especially true for the prehistoric and early historic periods where a rough coincidence between global or regional episodes of climatic deteriorations (e.g., Bond events during the Holocene) and a decrease in settlement density are considered sufficient evidence that human societies collapsed because of climatic change (cf. Rosen 2007). However, coincidence does not necessarily mean cause-effect and many (if not most) papers suggesting such a relationship lack any testable model of possible impact of climate on society that goes beyond the assumption that drought is bad. Climate fluctuates constantly and the amplitude of the Holocene climatic changes is usually lower than regular inter-annual variability (cf. Mackay et al. 2005). This implies that in research on climate/society relationship it is necessary to focus on society and its adaptability more than on climate. The model of climatic impact should first include the estimation of available resource (i.e., humans, animals, and cereals) allocation and relocation pathways and their frailty to the environmental conditions. Only something like the limited stress-test, even based on roughly estimated data that are available for ancient human societies, should be considered as a valid argument in favour of the hypothesis that climatic change (or any other environmental stress) led to an irreversible shift in the carrying capacity and to the collapse of local economy and - as a consequence - to social and political upheaval (cf. Xoplaki et al. 2015). While this path is much more difficult, the results may be more reliable than simple mechanical matching of climatic change and superficial evidence of troubles in an ancient society.

Open Access This article is distributed under the terms of the Creative Commons Attribution 4.0 International License (http://creativecommons.org/licenses/by/4.0/), which permits unrestricted use, distribution, and reproduction in any medium, provided you give appropriate credit to the original author(s) and the source, provide a link to the Creative Commons license, and indicate if changes were made.

\section{References}

Adalı SF (2009) Umman-manda and its significance in the first millennium B.C. Unpublished PhD dissertation, University of Sydney

Altaweel M (2008) Investigating agricultural sustainability and strategies in northern Mesopotamia: results produced using a socio-ecological modeling approach. J Archaeol Sci 35:821-835. doi:10.1016/j.jas.2007.06.012

Bridgman T (1998) Who were the Cimmerians? Hermathena 164:31-64

Brinkman JA (1968) A political history of Post-Kassite Babylonia 1158-722 B.C. Pontificium Institutum Biblicum, Roma

De Châtel F (2014) The role of drought and climate change in the Syrian uprising: untangling the triggers of the revolution. Middle Eastern Studies 50:521-535. doi:10.1080/00263206.2013.850076

Eph al I (2009) The city besieged: siege and its manifestations in the ancient Near East. Brill, Leiden \& Boston

Fales FM (1990) Grain reserved, daily rations, and the size of the Assyrian army: a quantitative study. State Archives of Assyria Bulletin 4:23-34

Fales FM (1996) Prices in Neo-Assyrian sources. State Archives of Assyria Bulletin 10:11-35

Fang J-Q, Liu G (1992) Relationship between climatic change and the nomadic southward migrations in Eastern Asia during historical times. Clim Chang 22:151-168. doi:10.1007/BF00142964

Fortin M (1997) Urbanisation et "redistribution" de surplus agricoles en Mésopotamie septentrionale (30002500 av. J.-C.). In: Aufrecht WE, Mirau NA, Gauley SW (eds) Urbanism in antiquity: from Mesopotamia to Crete. Sheffield Academic Press, Sheffield, pp. 50-81

Frame G (1999) A siege document from Babylon dating to 649 B.C. J Cuneif Stud 51:101-106

Hasel MG (2008) Assyrian military practices and Deuteronomy's laws of warfare. In: Kelle BE, Ames FR (eds) Writing and reading war: rhetoric, gender, and ethics in Biblical and modern contexts. Society of Biblical Literature, Atlanta, pp. 67-81 
Kaniewski D, Paulissen E, Van Campo E, et al. (2010) Late second-early first millennium BC abrupt climate changes in coastal Syria and their possible significance for the history of the Eastern Mediterranean. Quat Res 74:207-215. doi:10.1016/j.yqres.2010.07.010

Kaniewski D, Van Campo E, Guiot J, et al. (2013) Environmental roots of the Late Bronze Age crisis. PLoS One 8:e71004. doi:10.1371/journal.pone.0071004

Kirleis W, Herles M (2007) Climatic change as a reason for Assyro-Aramean conflicts? Pollen evidence for drought at the end of the 2nd millennium BC. State Archives of Assyria Bulletin 16:7-37

Mackay A, Battarbee R, Birks J, Oldfield F (eds) (2005) Global change in the Holocene. Oxford Univ. Press, New York

Masetti-Rouault MG (2010) Rural economy and steppe management in an Assyrian colony in the west. A view from Tell Masaikh, lower middle Euphrates, Syria. In: Kühne H (ed) Dūr-Katlimmu 2008 and beyond. Harrassowitz, Wiesbaden, pp. 129-149

McClellan TL (1992) 12th century B.C. Syria: comments on Sader's paper. In: Ward WA, Joukowsky M, Åström P (eds) The crisis years: the 12th century B.C. from beyond the Danube to the Tigris. Kendall/Hunt Pub, Dubuque, Iowa, pp. 164-173

Neumann J, Parpola S (1987) Climatic change and the 11th-10th century eclipse of Assyria and Babylonia. Journal of Near Eastern Studies 46:161-182

Parpola S (ed) (1993) Letters from Assyrian and Babylonian scholars. Helsinki University Press, Helsinki, Finland

Paulette T (2013) Consumption and storage in the Bronze Age. In: Wilkinson TJ, Gibson M, Widell M (eds) Models of Mesopotamian landscapes: how small-scale processes contributed to the growth of early civilizations. Archaeopress, Oxford, pp. 102-108

Pfälzner P (2002) Models of storage and the development of economic systems in the early Jezireh period. In: AlGailani Werr L (ed) Of pots and plans: papers on the archaeology and history of Mesopotamia and Syria presented to David Oates in honour of his 75th birthday. NABU, London, pp. 259-286

Rosen AM (2007) Civilizing climate: social responses to climate change in the ancient Near East. Altamira Press, Lanham

Schneider AW, Adalı SF (2014) "No harvest was reaped": demographic and climatic factors in the decline of the Neo-Assyrian empire. Clim Chang 127:435-446. doi:10.1007/s10584-014-1269-y

Van de Noort R (2011) Conceptualising climate change archaeology. Antiquity 85:1039-1048. doi:10.1017/ S0003598X00068472

Vargyas P (2001) A history of Babylonian prices in the first millennium BC. Heidelberger Orientverlag, Heidelberg

Wilkinson TJ, Wilkinson EB, Ur J, Altaweel M (2005) Landscape and settlement in the Neo-Assyrian empire. Bull Am Sch Orient Res 340:23-55

Xoplaki E, Fleitmann D, Luterbacher J, et al. (2015) The medieval climate anomaly and Byzantium: A review of the evidence on climatic fluctuations, economic performance and societal change. Quat Sci Rev. doi:10. 1016/j.quascirev.2015.10.004 